\title{
Performance evaluation of artificial wetlands with floating macrophytes (Lemnas) in the treatment of urban effluents
}

\begin{abstract}
The objective was to evaluate the behavior of surface wetlands with floating macrophytes, in the removal of biological oxygen demand $\left(\mathrm{BOD}_{5}\right)$, chemical oxygen demand (COD), total suspended solids (TSS), total nitrogen, total phosphorus and total coliforms from urban effluents. In our experiment, we selected two macrophyte population densities and two HRT (hydraulic retention time) in unfavorable weather conditions in the region of Río Cuarto, Córdoba, Argentina. In a second stage of the experiment, the total suspended solids removal was determined, with equal population densities and equal HRT, in spring. A wetland system was constructed at pilot scale with $50 \%$ and $100 \%$ of floating macrophytes coverage and two different HRT working in steady laminar flow in winter time, which included a system of regulated flow rates and a pond for disposing the effluents. Floating Lemnáceas family plants, known as duckweed were used, and three different repetitions were performed. According to results:

i. The best yields of wetlands in the removal of organic matter could be achieved with lower population densities of plants and longer hydraulic retention time;

ii. There were no significant influences of hrt or the density of plants in removing total nitrogen;

iii. There were significant influences with the lowest population density of plants in removing total phosphorus;

iv. There were no significant influences of independent variables for tss, or winter or spring;

v. There was significant decrease in tss by temperature increase of wetlands in spring;

vi. There were significant reductions in total coliforms under the influence of hrt these results let us conclude that surface wetlands with floating macrophytes, are highly efficient in the removal of total coliforms and organic matter in the treatment of urban effluents.
\end{abstract}

Volume 3 Issue 2 - 2019

\author{
Soler C,' Crespi R, ${ }^{2}$ Soler $E^{3}$ \\ 'Posgraduate school, Buenos Aires Regional School, National \\ Technological University,Argentina \\ ${ }^{2}$ Department Ecology Agraria, Faculty of Agronomy and \\ Veterinary, National University of Río Cuarto, Argentina \\ ${ }^{3}$ Department of Basic Sciences, Faculty of Agronomy and \\ Veterinary, National University of Río Cuarto, Argentina
}

Correspondence: Soler C, Posgraduate school, Buenos Aires Regional School, National Technological University, Argentina, Email cris_soler@hotmail.com

Received: July 29, 2018 | Published: April 03, 2019

\section{Introduction}

Currently, the treatment of sewage by conventional systems require high investment costs, operation and maintenance for which public funds are usually insufficient. As a result, in many cases, the effluents are discharged into natural waterways without treatment, polluting rivers and groundwater with consequent increased risk of waterborne diseases. To mitigate these environmental impacts, a number of unconventional alternatives may be applied for the artificial wetlands that have low cost of installation and maintenance, and operate with low power consumption. Addressing the economic aspect, implementing the use of Superficial Wetlands in the treatment of urban effluent means a significant decrease in power consumption, being useful in rural schools closed neighborhoods and small urban populations. Considering the social component, the need for maintenance of wetlands in terms of cleanliness and other work to achieve operational effectiveness thereof constitutes a source of labor genuine work, involving the inhabitants of the area where the system is implemented.

Finally from the environmental viewpoint, and taking into account the three pillars that make sustainability system, the contaminant removal accomplished supplemented with tertiary treatment allows the reuse of treated liquid in the irrigation of crops and green spaces as well also its use in aquaculture; recovering -in this way- the precious liquid so scarce in times of drought, reinserting it in the productive cycle as the production of fishmeal and reducing the environmental impact by avoiding pollution of surface and groundwater resources. In this work, the behavior of Biological Oxygen Demand (BOD $)_{5}$, Chemical Oxygen Demand (COD), total suspended solids (TSS), total nitrogen $(\mathrm{Nt})$, Total phosphorus $(\mathrm{Pt})$ and total coliforms was studied according to two plant population densities of $50 \%$ and $100 \%$ coverage of the surface of wetlands and two Hydraulic Retention Time (HRT) of 4 days and 1 day. The aim of this work, then consisted in evaluating the performance of a system surface wetlands with floating macrophytes with two plant population densities and two hydraulic retention time (TRH), in the removal of organic matter, total suspended solids, nutrients (total nitrogen and total phosphorus) and total coliforms, in winter season, with unfavorable weather conditions.

\section{Concepts on wetlands}

Artificial wetlands consist of a monoculture or polyculture of higher plants (macrophytes) arranged in ponds, tanks or shallow 
channels. The effluent, after receiving a pre-treatment, passes through the wetland where it is subjected to physico-chemical and microbiological processes for a certain retention time. The oxygen required for these processes is supplied by photosynthesis of the plants themselves or taken from the air by them, to be injected into the root zone. The oxygen transfer to the root zone by these aquatic plants, is essential for the microbial removal of some contaminants, further stimulating the degradation of organic matter and growth of nitrifying bacteria. ${ }^{1}$ The main functions of aquatic plants are aerate the root system and provide oxygen to the microorganisms living in the rhizosphere, absorption of nutrients (nitrogen and phosphorus), removing contaminants assimilating directly in their tissue and filtration of the solids through the framework that forms its root system. Aquatic plants are involved in these processes of removal. Some of them pump oxygen to their submerged petioles, roots and stems. Oxygen is used by microbes performing decomposition, and attached to aquatic plants under the water level. ${ }^{2}$

The constructed wetlands are used to treat a range of wastewaters:

a. Domestic and urban water.

b. Industrial water, including papermaking, chemical and pharmaceutical products, cosmetics, food, refineries and slaughterhouses among others.

c. Drainage of mining operations.

d. Water from agricultural and urban runoff.

e. Sludge treatment of conventional depuration plants by surface arrangement on subsurface flow wetlands where they dehydrate and mineralize. ${ }^{3}$

Constructed wetlands are categorized according to their flow patterns: surface or subsurface.

There are three lines of technological development of artificial wetlands, whose mode of action is different, even based on the same biological principles. These are:

(i) Wetlands or free flow surface (FWS),

(ii) Wetlands subsurface flow (SBF), and

(iii) Wetlands with species floating on the water surface. The latter type of systems that work naturally, contain floating plants such as water hyacinth (Eichornia crassipes) Or duckweed (Lemna spp.), and use emerging species that are made to float. In the latter group, floating macrophyte filter, developed in Spain and patented by the Polytechnic University of Madrid (UPM) was included.

Artificial wetlands free flowing, raceways or ponds consist of slope walls, where these and the bottom cover are tight (impermeable materials), to prevent water percolation susceptible to contamination of groundwater. Each system has appropriate inlet and outlet to ensure a uniform distribution of applied wastewater and harvesting structures. ${ }^{4,5}$ Emergent vegetation used in wetlands FWS includes the cattails (Typha spp.), rushes (Scirpus spp.) and reeds (Phragmites spp.). In wetlands subsurface flow (SBF), the influent flow is horizontal subsurface type, because of the water below the surface of the system. ${ }^{1}$ In a wetland SBF, no column continuous water, the influent flows through a porous bed of sand and/or gravel of variable thickness, holding the vegetation (hydrophytes or hygros). This bed is designed so as to allow the flow of wastewater through horizontal flow or vertical flow through the root system of aquatic macrophytes. The effluent is treated through various physicochemical and bacteriological processes. In systems subsurface flow sheet there is no water in sight of the observer. An artificial wetland SBF is specifically designed for wastewater treatment or for final treatment stage is constructed as a bed or channel containing an appropriate medium. The means used may be crushed rock, gravel, sand and other soil materials. The medium is typically ground with the same types of emerging vegetation present on the flooded meadows and, by design, the water level remains below the surface of the medium. ${ }^{5}$ SBF wetlands are one or more channels shallow and coated to prevent percolation water table susceptible to contamination background. The type of coating depends on the soil conditions. In some cases local soil compaction is adequate, while in others addition of clay or plastic coating membranes, Polyvinyl Chloride (PVC) or High Density Polyethylene (PAD) is required. Emergent vegetation used in wetlands SBF includes the cattails and bulrushes (Typha spp.), rushes (Scirpus spp.) and reeds (Phragmites spp.). SBF wetlands horizontal flow, the water flows horizontally through the granular media and rhizomes and roots of plants. SBF species used in horizontal flow systems are typical emergent macrophytes of wetlands and reed (Phragmites), cattail (Typha) or the bulrushes (Scirpus). SBF vertical flow wetlands were developed in Europe as an alternative to the horizontal wetlands to produce nitrified effluents. Generally in SBF systems the vertical flow is combined with horizontal flow so that nitrification and denitrification occurs gradually, leading to elimination of nitrogen.

\section{Contaminant removal}

In artificial wetlands, contaminants in wastewater are removed by a number of physical, chemical and biological processes that take place in the natural environment, among these processes are sedimentation, adsorption to the soil particles, the assimilation by plants and microbial transformation. ${ }^{6}$ In photosynthesis, the floating macrophytes employ oxygen and carbon dioxide from the atmosphere. The nutrients are taken from the water column through the roots, which are also a means for infiltration/adsorption to suspended solids and bacterial growth. Root development depends on the availability of nutrients in the water and nutrient demand by the plant. Consequently, density and media depth of treatment -for example, roots of plants-are affected by water quality, pretreatment and factors affecting the rate of plant growth, such as temperature and harvesting scheme.?

\section{Suspended solids removal}

Most of the suspended and settleable solids are removed in the pretreatment and wetlands filter and settle the remaining complementing this removal. Macrophyte roots and the substrate reduce water velocity favoring both processes. ${ }^{3}$ In free flow systems (surface flow) the suspended solids are removed by mechanisms of flocculation/sedimentation and filtration/Intercept. ${ }^{1}$ It should be noted that besides solids containing influent, the system may also generate due to remains of plants, microorganisms and precipitates. Sedimentation occurs by gravity, and under ideal conditions is governed by Stokes' law, which states that the sedimentation rate is proportional to the square of the particle diameter and inversely proportional to fluid viscosity. In turn, the viscosity of a liquid decreases with temperatura. ${ }^{8}$ Saber et al., ${ }^{9}$ conducted an experiment of domestic effluent treatment on pilot scale reactor consisting of a UASB and three gaps with Lemnas gibba connected in series. Each pond had a surface of $1 \mathrm{~m}^{2}$ and $0,48 \mathrm{~m}$ depth. HRT was 5 days in each pond. It indicates that the removal of TSS probably depends primarily on HRT and that greater HRT treatment system Lemna gibba ponds 
no longer depends on the temperature, but may be affected by this, for low HRT.

The effects of temperature may be significant for sedimentation processes. ${ }^{10}$ It has been shown that a temperature differential of $1{ }^{\circ} \mathrm{C}$ between the influent waste liquid and residual liquid in a sedimentation tank; will result in the formation of a density current. Accordingly, if the temperature of the influent is higher than the temperature of the liquid located in the sedimentation tank a thermal stratification will occur such that the incoming flow at higher temperatures will shift on the colder liquid in the tank sedimentation, where a dead space will be formed.

\section{Removal of organic matter}

The removal of organic matter takes place mainly by aerobic microbiological or anaerobic biodegradation, depending on the presence of dissolved oxygen. A small portion is also removed by physical processes such as sedimentation and filtration, when organic matter is attached to the suspended solids. ${ }^{3}$ Biodegradation is carried out by microorganisms which are attached to plants, in particular to roots and sediment surface. ${ }^{3}$ All microorganisms involved in the degradation process require a source of energy and carbon for the synthesis of new cells, as other nutrients and trace elements. According to their source of nutrients, they are classified as heterotrophic and autotrophic. Heterotrophs require organic material as a carbon source for the synthesis of new microorganisms, however, autotrophs utilize carbon dioxide as a carbon source. ${ }^{3}$ An indicator of the amount of organic substances of biological origin (proteins, carbohydrates, fats and oils), and synthetic organic and biodegradable chemicals in the waste water is the biochemical oxygen demand $\left(\mathrm{BOD}_{5}\right){ }^{11}$ To measure the organic material present in the waste water susceptible of being chemically oxidized the chemical oxygen demand (COD), analysis was done by oxidation with a dichromate solution in an acid medium. Saber et al, (2004) indicated that removal of COD, BOD and TSS probably depends primarily on HRT and that greater HRT treatment system of lagoons of Lemna gibba no longer depends on the temperature, but may be affected by this for HRT low.

\section{Nitrogen removal}

The temperature is most influential on the growth of nitrifying bacteria operational factor. There is a significant reduction in the rate of nitrification with decreasing temperature. In contrast, the growth rate of nitrifying bacteria increases considerably with temperature in the range of $8^{\circ} \mathrm{C}$ to $30^{\circ} \mathrm{C}$, an increase of $10 \%$ for each $1{ }^{\circ} \mathrm{C}$ temperature rise in the genus Nitrosomonas, ${ }^{12}$ Below $10^{\circ} \mathrm{C}$ the nitrification rate drops abruptly. Above $10^{\circ} \mathrm{C}$ the nitrification increases almost in proportion to the temperature. Nitrosomonas have an optimal growth rate at $30^{\circ} \mathrm{C}$, therefore, generally this is considered ideal for the nitrification process temperature. Below $4^{\circ} \mathrm{C}$ no growth of Nitrosomonas and Nitrobacter. ${ }^{12}$ Denitrification is the final step in nitrogen removal. Occurs under anoxic conditions, i.e., without dissolved oxygen; or with less than $2 \%$ of saturation concentration, but where the oxygen is available sources such as nitrate, nitrite or sulfate. Similar to the process of nitrification, denitrification is also strongly temperature dependent, and requires sufficient carbon as an energy source for the bacteria to do the conversion. Saber et al., ${ }^{9}$ notes that most of the removal of $\mathrm{N}$ depends on the growth rate of the duckweed and a lower percentage occurs by sedimentation and denitrification processes. It also states that during the winter season, the growth rate of the duckweed by low temperature $\left(13-20^{\circ} \mathrm{C}\right)$ was significantly reduced and consequently decreased nutrient recovery.

\section{Phosphorus removal}

Phosphorus is present as orthophosphate, polyphosphate and organic phosphate. Organic phosphate and polyphosphates, require subsequent decomposition to a more assimilable orthophosphate. ${ }^{3}$ Processes of phosphorus removal are the physicochemical type. The phosphorus which is in the form of (solid) particles can be deposited by sedimentation on the bottom of the wetland, or trapped between the submerged parts of the emerging plants and adhere on the surface forming biofilms, being susceptible to other processes of biological Type. ${ }^{1}$ The soluble phosphorus dynamics includes physicochemical adsorption/absorption, exchange, precipitation, solubilization, and redox. The adsorption/absorption biofilms occur on plants and waste and wetland sediments. In sediments often occur an intensive exchange of phosphorus with the water column.

In biological transformation processes of phosphates, dissolved organic phosphorus, organic phosphorus and insoluble particulate phosphorus are not available for plants unless be transformed into soluble inorganic phosphorus. In wetlands these transformations can occur through the intervention of microorganisms that have been suspended as biofilms on surfaces of emerging plants and sediments. Once solubilized, it can be assimilated by plants and other organismsbacteria, algae- and therefore be temporarily removed from the water.

Phosphorus removal is primarily due to the deposition and immobilization of phosphates in the sediment; vegetation in turn, contributes phosphorus extractions, provided that the biomass is removed from the system. Considerably, phosphorus is one of the essential macronutrients for the growth of microalgae. It is taken as orthophosphate $\left(\mathrm{P}_{-} \mathrm{PO}_{4}^{-3}\right)$, whose concentration depends on the $\mathrm{pH}$ of the medium. There are factors that slow down the taking of orthophosphate by the algae, such as an excessively high or low $\mathrm{pH} .{ }^{13}$

\section{Bacteria removal}

The removal of these microorganisms is based on a combination of physical, chemical and biological factors. Physical factors include filtration, sedimentation, aggregation and action of ultraviolet radiation. Biological mechanisms include, predation and attack by bacteriophages, and death (declination die-off). Finally, chemical factors are oxidation, adsorption and exposure to toxins set by other microorganisms and exuded by the root of the plants.

\section{Material and methods}

The work was carried out in 2013, at the Pilot Treatment and Effluent Reuse Urban Plant of the National University of Río Cuarto (UNRC), Córdoba, Argentina. This plant processes a flow of 25,000 $\mathrm{Ld}^{-1}$ of wastewater generated by a residential complex of 130 students who stay in the University Student residence (REU) of UNRC. In the Pilot Plant, the treatment of liquid effluents is carried out by a pretreatment, primary treatment and secondary treatment, as explained below:

\section{Pretreatment}

REU effluents, discharged to a receiving chamber (Figure 1), where the material passes through a perforated stainless steel disc which acts as a first thick- prefilter material is, then poured by gravity into a steel cup stainless covered with perforations to operate as a second prefilter retaining the bulk might have passed the perforated disk. Every week the basket is retracted for cleaning, washed again and inserted in place. ${ }^{14}$ 


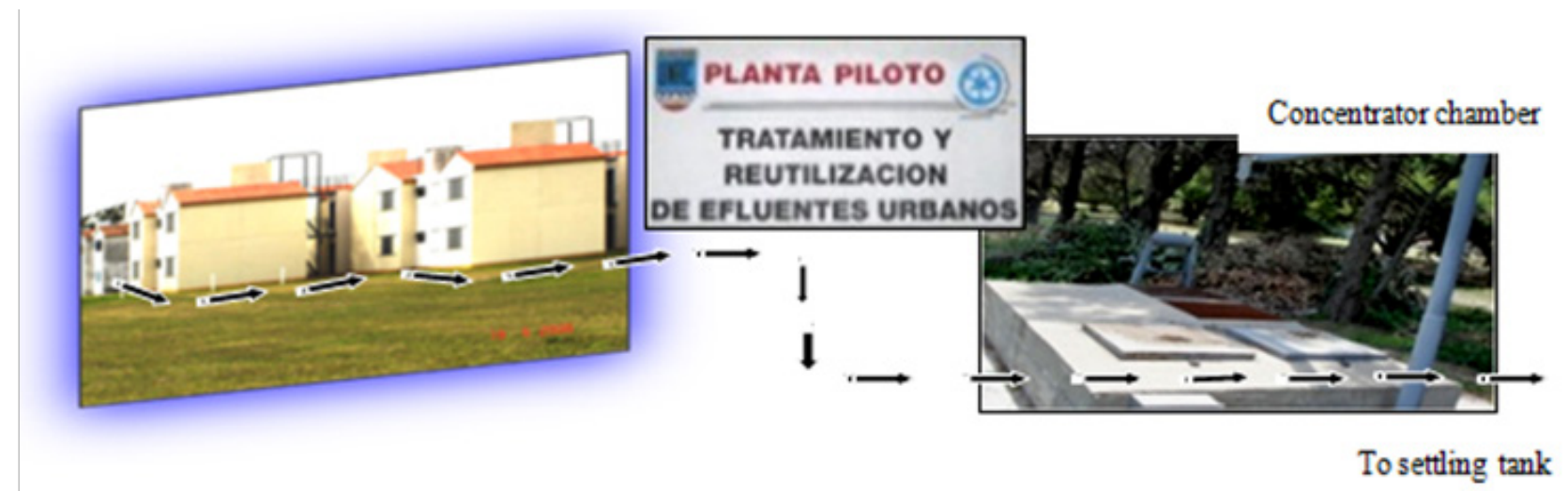

Figure I Pretreatment. Concentrator urban effluent chamber. UNRC, Río Cuarto, Córdoba, Argentina. ${ }^{14}$

\section{Primary and secondary wastewater treatment}

The receiving chamber accommodates two centrifugal pumps, which operate automatically whenever the chamber is stored in a volume of $3000 \mathrm{~L}$ effluent, sending to a sedimentation tank sludge 10,000 L capacity. From the settling tank sludge, separated liquids are referred to facultative lagoons with aquatic macrophytes for secondary treatment. ${ }^{14}$

\section{Experiment}

In order to achieve the proposed objective, an experimental research was conducted to evaluate the decreased concentrations of $\mathrm{BOD}_{5}$ (biochemical oxygen demand), COD (chemical oxygen demand), TSS (Total Suspended Solids) Nt (total nitrogen), Pt (total phosphorus) and Total Coliforms from urban effluents coming from Student Housing University (REU) of the National University of Rio Cuarto, after being treated by Wetlands Superficial with floating macrophytes (Lemnas), the varying the density of plants and hydraulic retention time (HRT) in winter season, with unfavorable climatic conditions for plant growth. In a second step, the TSS concentration in spring season was evaluated with higher temperatures. Six surface wetlands were constructed which scaled $2.10 \mathrm{~m}$ long, $0.90 \mathrm{~m}$ wide and $0.70 \mathrm{~m}$ deep, with a gradient of $1 \%$. Sampler wells $0.50 \mathrm{~m}$ long, $0.30 \mathrm{~m}$ wide and $0.20 \mathrm{~m}$ deep were prepared. To complete the system a discharge pond of $2.00 \mathrm{~m}$ long, $1.00 \mathrm{~m}$ wide and $1.00 \mathrm{~m}$ deep was dug. Three wetlands were designed to accommodate floating plants, with a seeding density of $100 \%$ and the other three, conditioned with plant density of $50 \%$. Assigning densities was randomized, and for this draws wetland was performed (Figures 2-4). Floating plants used were duckweed, 4 genera of the family of Lemnáceas (Wolffia, Wolffiela, Lemna and Spirodella). Variations of HRT were 1 day and 4 days, in laminar flow. In order to ensure laminar flow wetlands were fed:

a. A continuous flow of sewage effluent $6 \mathrm{Lh}^{-1}$ for an HRT of 4 days.

b. A continuous flow of sewage effluent $25 \mathrm{Lh}^{-1}$ for a HRT of 1 day.

Feeding wetlands with influent, was performed by derivatization with PVC pipe $50 \mathrm{~mm}$ in diameter and valve manifold system from a stabilizing pressure tank $1000 \mathrm{~L}$ with automatic floating, to maintain a constant load height of $1.2 \mathrm{~m}$ in flow wetlands. This tank was fed, from the settling tank sludge. The experiment was factorial with two fixed factors: plant population density and HRT. Plant population density levels with two categories: $50 \%$ (D1) and 100\% (D2), surface coverage of wetlands. Meanwhile HRT in continuous laminar flow, with two levels of categories: measured at 4 days (HRT 1) and one day (HRT 2), respectively in the period between 24.8.2013 and 29.8.2013 with waste effluent temperatures varying between 5 and $15{ }^{\circ} \mathrm{C}$. In a second stage, the experiment was repeated for TSS, in the period between 30.11.2013 and 12.05.2013, with wetland temperatures varying between 16 and $23{ }^{\circ} \mathrm{C}$. Thus, two treatment groups with 3 repetitions per every plant density were evaluated together with two hydraulic retention times were formed.

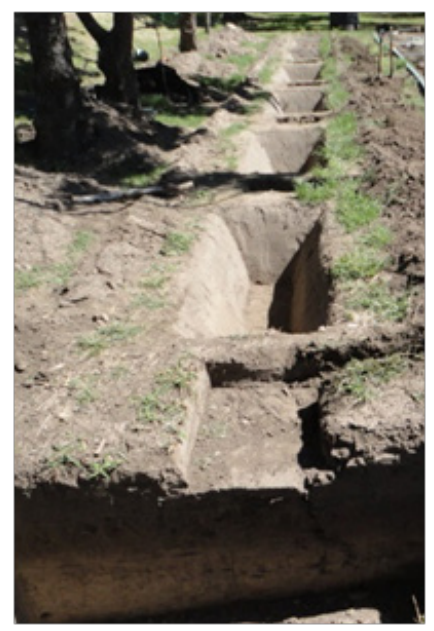

Figure 2 Excavation wetlands.

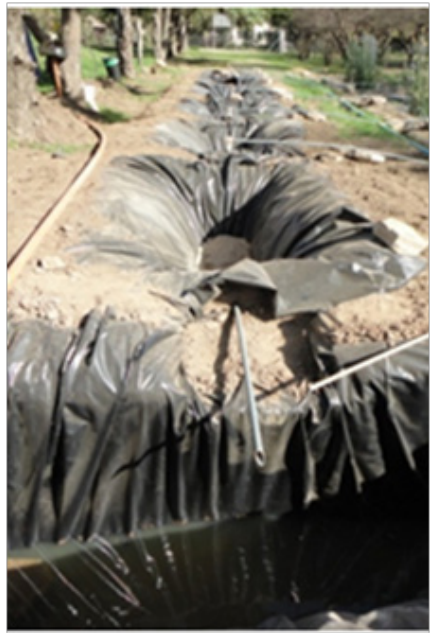

Figure 3 Constrution of wetlands. 


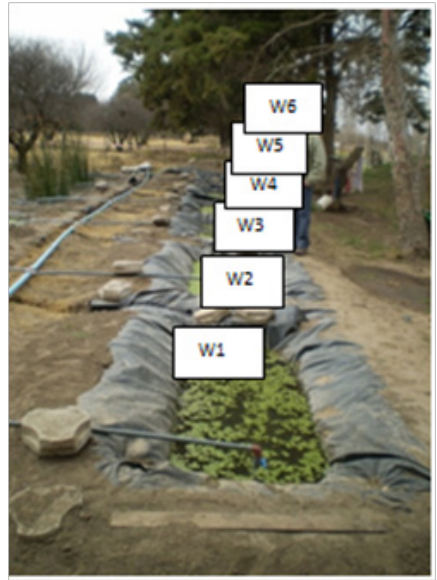

Figure 4 Operable wetlands.

The random drawing of wetlands assigned the following distribution:

a. Wetlands H1, H3 and H6 density (D1) 50\% of plants.

b. Wetlands H2, H4 and H5 density (D2) 100\% of plants.

The experiment results were evaluated using the Statical Package for the Social Science (S.P.S.S.) with the following techniques:

An analysis of General Linear Model (GLM) (Soler, 2009) with two fixed factors and interaction, in order to study the combined influence of both factors (density and HRT) for each of the variables $\mathrm{BOD}_{5}$, COD, TSS was performed, Nt, Pt and total coliforms, resulting in no significant interaction DENSITY * TIME.

The model was evaluated:

$\mathrm{Yi}=$ Intercept + DENSITY + TIME + DENSITY $*$ TIME + Error

Where $\mathrm{Yi}$ is $\mathrm{BOD}_{5}$, or COD, or TSS, oro $\mathrm{r} \mathrm{Nt}$, Pt or total coliforms

The analytical methods used were the standard methods for the Examination of Water and Wastewater. ${ }^{15}$
Total nitrogen - Method 4500-Norg Macro-Kjeldahl Method B.

Total phosphorus -Method 4500-P Phosphorus'

$\mathrm{BOD}_{5}$ - Test Method 5210 B. DBO days; $^{2}$

COD - COD D. Test Method 5220. Closed reflux colorimetric method;

Total suspended solids - Method B. 2540 Total dry solids at $103^{\circ} \mathrm{C}$ $-105^{\circ} \mathrm{C}$;

Total coliforms - Standard Method 9221 B. Technical Standard fermentation of total coliforms.

\section{Results}

Influent characteristics shows in Table 1. For statistical analysis, a General Linear Model (GLM) ${ }^{16}$ with two fixed factors and interaction purposes, to study the combined influence of both factors (density and HRT) was applied, resulting in no significant DENSITY *HRT interaction; consequently the General Linear Model analysis (GLM) with two fixed model without interaction factors for each of the variables $\mathrm{BOD}_{5}, \mathrm{COD}, \mathrm{TSS}, \mathrm{Nt}, \mathrm{Pt}$ and total coliforms was repeated to obtain a better grade of adjustment (Table 2).

Table I Influent characteristics

\begin{tabular}{lll}
\hline Parameter & Inflow in winter & Inflow in spring \\
\hline Temperature $\left({ }^{\circ} \mathrm{C}\right)$ & 14 & 26 \\
$\mathrm{BOD}_{5}\left(\mathrm{mg} \mathrm{O}_{2} \mathrm{~L}^{-1}\right)$ & 134.6 & - \\
$\mathrm{COD}\left(\mathrm{mg} \mathrm{O}_{2} \mathrm{~L}^{-1}\right)$ & 263.2 & - \\
Total suspended solids $\left(\mathrm{mg} \mathrm{L}^{-1}\right)$ & 510 & 224 \\
Total nitrogen $\left(\mathrm{mg} \mathrm{L}^{-1}\right)$ & 38.53 & - \\
Total phosphorus $\left(\mathrm{mg} \mathrm{L}^{-1}\right)$ & 2.4 & - \\
Total coliforms $\left(\mathrm{mpn}^{*} 105 / 100 \mathrm{~mL}\right)$ & 240 & - \\
Nmp I0.02 $\mathrm{mL}^{-1}$ & &
\end{tabular}

Table 2 Test of the effects inter-subject

\begin{tabular}{|c|c|c|c|c|c|c|c|}
\hline & $\mathrm{DBO}_{5} \mathrm{mg} \mathrm{O}_{2} \mathrm{~L}^{-1}$ & COD $\mathrm{mg} \mathrm{O}_{2} \mathrm{~L}^{-1}$ & TSS (winter) mg L-I & TSS (spring) mg L-1 & NT $\mathbf{m g ~ \mathbf { L } ^ { - 1 }}$ & PT mg L L & $\begin{array}{l}\text { Total coliforms } \\
\text { MPN/I00 mL }\end{array}$ \\
\hline & $\mathbf{p}$ & $\mathbf{p}$ & $\mathbf{p}$ & $\mathbf{p}$ & $\mathbf{p}$ & $\mathbf{p}$ & $\mathbf{p}$ \\
\hline Density & 0.003 & 0.002 & 0.37 & 0.315 & 0.783 & 0.016 & 0.232 \\
\hline $\mathrm{TRH}$ & 0.015 & 0.011 & 0.591 & 0.842 & 0.367 & 0.212 & 0 \\
\hline $\mathrm{R} 2$ & 0.673 & 0.698 & 0.078 & 0.078 & 0.102 & $0.44 I$ & 0.913 \\
\hline
\end{tabular}

Model tested:

$\mathrm{Yi}=$ Intercept + DENSITY + TIME + Error

Where Yi: $\mathrm{BOD}_{5}, \mathrm{COD}$, TSS, Nt, Pt and total coliforms

Assessment test assumptions were made with Levene test for a probability $p>0.24$ in order to give a safety margin and verify the homogeneity of variance.

From Table 2, it can be seen that:

i. Density and HRT, have significant influence on COD and $\mathrm{BOD}_{5}$ with probabilities $(\mathrm{p}=0.003 ; \mathrm{p}=0.015)$ and $(\mathrm{p}=0.002$; $\mathrm{p}=0.011$ ) respectively. ii. HRT and density have no influence on TSS neither winter nor spring, with probabilities $(\mathrm{p}=0.370 ; \mathrm{p}=0.591)$ and $(\mathrm{p}=0.315$; $\mathrm{p}=0.842$ ) respectively.

iii. Density and HRT have no influence on NT with probabilities $(\mathrm{p}=0.783 ; \mathrm{p}=0.367)$

iv. Density has significant influence on PT with probability $\mathrm{p}=0.016$; however HRT does not influence PT $(\mathrm{p}=0.212)$

v. Density has no effect on Total Coliforms, probability $\mathrm{p}=0.232$; However, HRT has high influence on the removal of Total Coliform $(\mathrm{p}=0.000)$. 
vi. The determination coefficient $\mathrm{R}^{2}$ indicates that both the density and the HRT contribute $67.3 \%, 69.8 \%, 91.3 \%, 44.1 \%$ to the removal of $\mathrm{BOD}_{5}, \mathrm{COD}, \mathrm{PT}$ and Total Coliforms, respectively.

In order to facilitate the preparation of conclusions about the behaviour of each of the variables under study, illustrative charts with the results of the experiment and the raw data obtained from laboratory report were developed.

\section{BOD $_{5}$ (biochemical oxygen demand)}

Parameter Influent: $134.6\left(\mathrm{mg} \mathrm{O}_{2} \mathrm{~L}^{-1}\right)$

Plotting raw data of $\mathrm{BOD}_{5}$ obtained from laboratory tests, you can see the result of the experiment together (Figure 5).

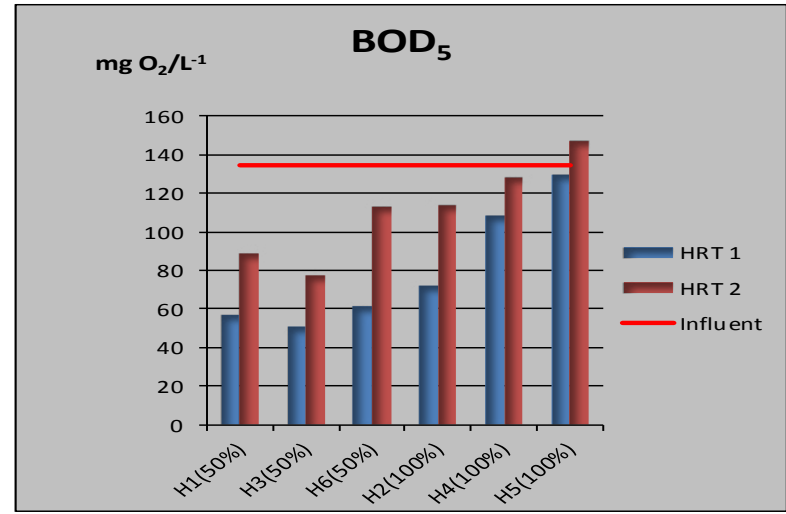

Figure $\mathbf{5}$ Variation of $\mathrm{BOD}_{5}$ depending on plant density and HRT. that:

The descriptive statistics for the dependent variable $\mathrm{BOD}_{5}$ indicate

a. For $50 \%$ plant density, HRT1 and HRT2, obtained averages were 56.4 and $93 \mathrm{mg} \mathrm{O}_{2} \mathrm{~L}^{-1}$ respectively, under the parameter of the influent $136.4 \mathrm{mg} \mathrm{O}_{2} \mathrm{~L}^{-1}$.

b. For $100 \%$ plant density, HRT1 and HRT2, obtained averages were 103.3 and $129.8 \mathrm{mg} \mathrm{O}_{2} \mathrm{~L}^{-1}$, respectively, under the parameter of the influent $136.4 \mathrm{mg} \mathrm{O}_{2} \mathrm{~L}^{-1}$; but higher than those obtained for $50 \%$ of plant density.

c. For HRT1 with densities of $50 \%$ and $100 \%$ coverage of plants, the removal was greater than for HRT2.

\section{COD (Chemical Oxygen Demand)}

Parameter Influent: $263.2\left(\mathrm{mg} \mathrm{O}_{2} \mathrm{~L}^{-1}\right)$

Graphing the raw data obtained from the COD laboratory tests, you can see the result of the experiment together (Figure 6):

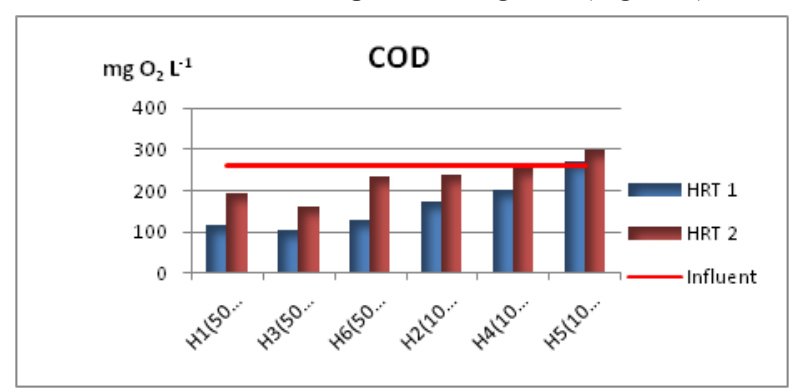

Figure 6 Variation of COD depending on plant density and HRT. that:

The descriptive statistics for the dependent variable COD indicate

Citation: Soler C. Performance evaluation of artificial wetlands with floating macrophytes (Lemnas) in the treatment of urban effluents. Int J Hydro. 2019;3(2):I29-136. DOI: I0.15406/ijh.2019.03.00I74 a. For $50 \%$ plant density, HRT1 and HRT2, obtained averages were 114.6 and $194.93 \mathrm{mg} \mathrm{O}_{2} \mathrm{~L}^{-1}$, respectively, under the parameter of the influent $263.2 \mathrm{mg} \mathrm{O}_{2} \mathrm{~L}^{-1}$.

b. For $100 \%$ plant density, HRT1 and HRT2, obtained averages were 214.4 and $262.43 \mathrm{mg} \mathrm{O} \mathrm{L}^{-1}$, respectively, under the parameter of the influent $263.2 \mathrm{mg} \mathrm{O}_{2} \mathrm{~L}^{-1}$; but higher than those obtained for $50 \%$ of plant density.

c. For TRH1 with densities of $50 \%$ and $100 \%$ coverage of plants, the removal was greater than for HRT2.

\section{TSS (total suspended solids) in winter season}

Parameter influent: $510\left(\mathrm{mg} \mathrm{L}^{-1}\right)$

Plotting raw data of TSS obtained from laboratory tests, you can see the result of the experiment together (Figure 7):

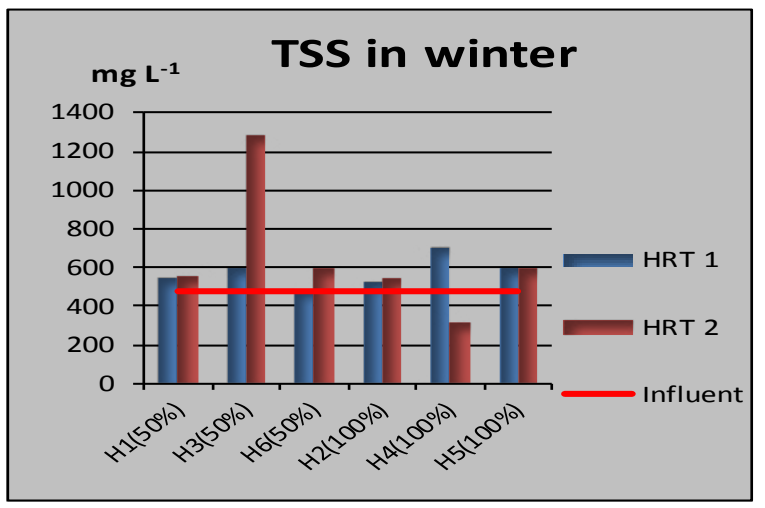

Figure 7 Variation of TSS depending on plant density and HRT in winter season.

In the above graph it shows that all samples have similar values, except the wetland H3 50\% with HRT2, which has an anomalous value justified by the laboratory, high turbidity reported in that sample.

Descriptive for the dependent variable statistical TSS during winter indicate that:

a. For $50 \%$ and $100 \%$ of plant density and HRT1 and HRT2, obtained averages were greater than influent of $510 \mathrm{mg} \mathrm{L}^{-1}$.

\section{TSS (total suspended solids) in spring}

Parameter influent: $224\left(\mathrm{mg} \mathrm{L}^{-1}\right)$

Plotting raw data of TSS obtained from laboratory tests, you can see the result of the experiment together (Figure 8):

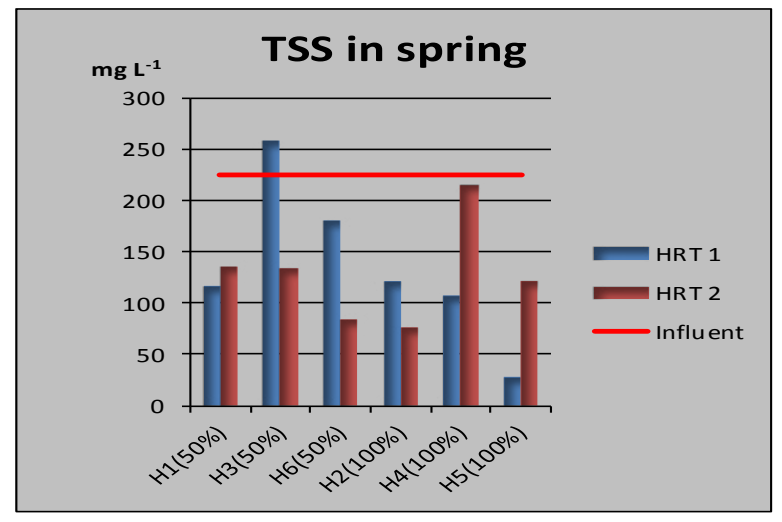

Figure 8 Variation of TSS depending on plant density and HRT in spring season. 
The descriptive statistics for the dependent variable SST spring indicate that:

a. For $50 \%$ plant density, TRH1 and TRH2, averages of 184.80 and $118 \mathrm{mg} \mathrm{L}^{-1}$ respectively, were obtained under the parameter of the influent of $224 \mathrm{mg} \mathrm{L}^{-1}$.

b. For $100 \%$ density, TRH1 and TRH 2 plants and stockings 86 and $137.53 \mathrm{mg} \mathrm{L}^{-1}$, respectively, were obtained under the parameter of the influent of $224 \mathrm{mg} \mathrm{L}^{-1}$

c. It also shows that the influent parameter in the spring is 224 $\mathrm{mg} \mathrm{L}^{-1}$, significantly lower than the influent during the winter of $510 \mathrm{mg} \mathrm{L}^{-1}$.

\section{Total Nitrogen}

Influent parameter: $38.53\left(\mathrm{mg} \mathrm{L}^{-1}\right)$

Plotting raw data obtained from the NT laboratory analysis, you can see the result of the experiment as a whole (Figure 9):

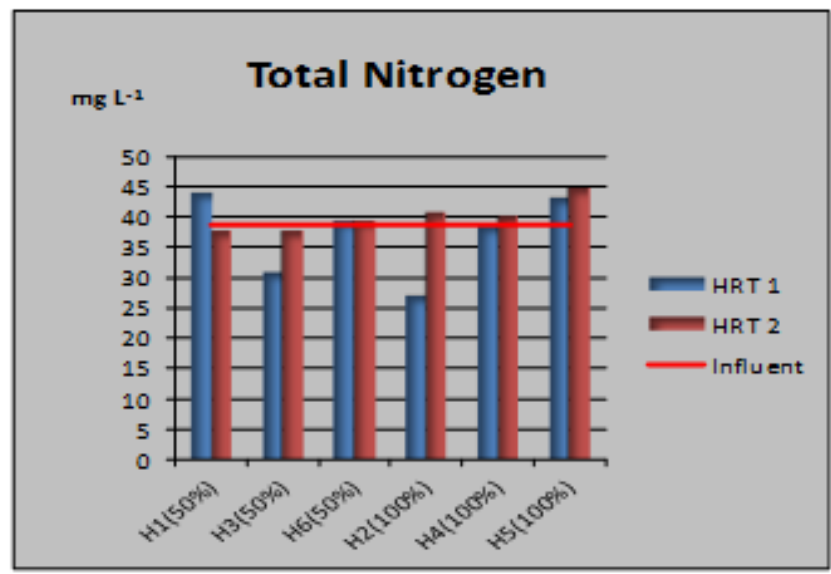

Figure 9 Variation of $\mathrm{Nt}$ depending on plant density and TRH. that:

The descriptive statistics for the dependent variable NT indicate

a. For 50\% plant density, TRH1 and TRH2, stockings 38.01 and $38.29 \mathrm{mg} \mathrm{L}^{-1}$ were obtained, respectively, without significant variation from the parameter influent of $38.53 \mathrm{mg} \mathrm{L}^{-1}$.

b. For $100 \%$ plant density, TRH1 and TRH2, stockings 36.22 and $41.86 \mathrm{mg} \mathrm{L}^{-1}$ were obtained, respectively, without significant variation from the parameter influent of $38.53 \mathrm{mg} \mathrm{L}^{-1}$.

\section{Total Phosphorus}

\section{Parameter Influent: $2.4 \mathrm{mg} \mathrm{L}^{-1}$}

Plotting raw data of PT obtained from laboratory tests, you can see the result of the experiment together (Figure 10): that:

The descriptive statistics for the dependent variable PT indicate

a. For $50 \%$ of plant density, TRH1 and TRH2, averages of 2.1 and $2.13 \mathrm{mg} \mathrm{L}^{-1}$ respectively, were obtained under the parameter regarding the influent of $2.4 \mathrm{mg} \mathrm{L}^{-1}$.

b. For $100 \%$ plant density, TRH1 and TRH2 results showed no influence of the independent variables on the removal of total phosphorus.

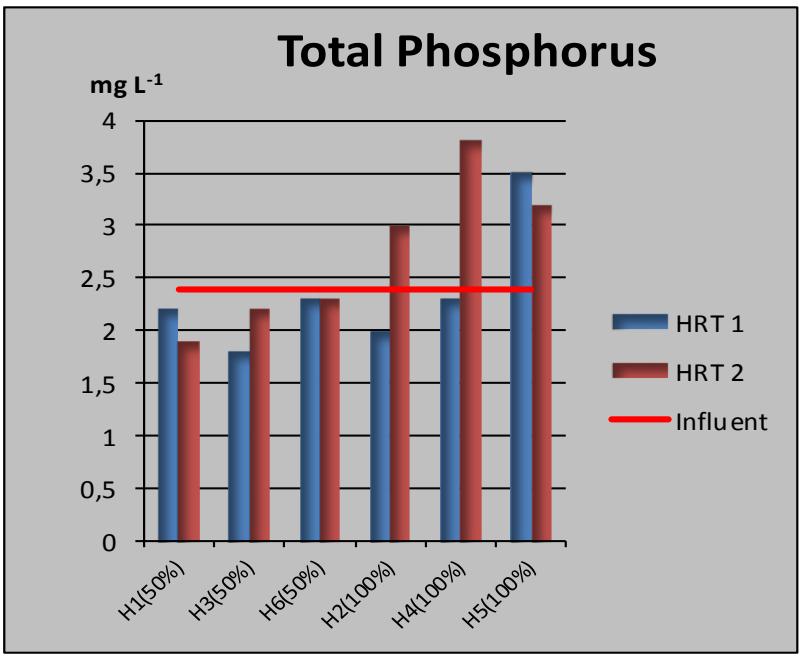

Figure 10 Pt variation depending on plant density and HRT.

\section{Total coliforms}

Parameter influent: $2.4 * 10^{7} \mathrm{MPN} / 100 \mathrm{ml}$

The descriptive statistics for the dependent variable Total Coliforms indicate that (Figure 11):

a. For $50 \%$ of plant density, HRT1 and HRT2, averages 9.24 and $22.07 \mathrm{NMP} * 10^{5} / 100 \mathrm{~mL}$, respectively were obtained, lower than parameter of influent $240 \mathrm{NMP} * 10^{5} / 100 \mathrm{~mL}$.

b. For $100 \%$ plant density, HRT1 and HRT2averages 9.6 and $25.07 \mathrm{NMP}^{*} 10^{5} / 100 \mathrm{~mL}$ respectively, which is lower than parameter of influent $240 \mathrm{NMP} * 10^{5} / 100 \mathrm{~mL}$.

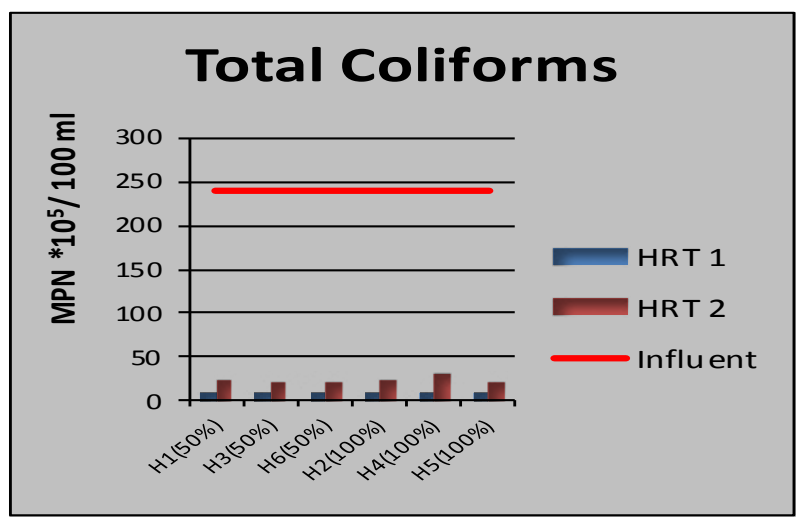

Figure I I Variation of Total Coliforms depending on the plant density and HRT.

\section{Conclusions}

From the results presented, we conclude that (Table 3):

i. The Density of plant cover significantly influences the $\mathrm{BOD}_{5}$ and $\mathrm{COD}$, obtaining better performance at lower $\%$ coverage of macrophytes (Lemnas).

ii. The Hydraulic Retention Time also significantly influences the $\mathrm{BOD}_{5}$ and $\mathrm{COD}$, yielding better performance at longer hydraulic retention times.

iii. There is no evidence that both the Density and the Hydraulic Retention Time have influence on Total Suspended Solids 
(TSS) in winter time. These results are explained, meaning that besides solids containing influent the system may also generate due to remains of plants, microorganisms and precipitates.

iv. There is no evidence that both the Density and the Hydraulic Retention Time have influence on Total Suspended Solids (TSS) in spring time, therefore, the values of TSS removed are attributed solely to the temperature rise in wetlands because increased sedimentation rate since this is inversely proportional to the viscosity according to Stokes law, and the viscosity decreases with Temperature. ${ }^{8}$

v. Neither Plant density or the Hydraulic Retention Time influenced Total Nitrogen removal under the conditions of this work. vi. The Density of plant cover significantly influences the Total Phosphorus obtaining better performance at lower $\%$ coverage of plants.

vii. The Density of plant cover does not significantly influence the removal of total coliforms.

viii. The Hydraulic Retention Time influences and is highly significant on the removal of total coliforms having been obtained in this experiment, yields of $96 \%$ to longer Hydraulic Retention Time.

ix. It would probably be necessary to experiment with longer Hydraulic Retention Time to those adopted for this experiment, in order to obtain variations in the results of NT and TSS. ${ }^{17}$

Table 3 Influences the BOD5 and COD

\begin{tabular}{|c|c|c|c|c|c|c|c|c|}
\hline \multirow{2}{*}{ Plant density } & \multirow{2}{*}{ THR } & \multicolumn{7}{|c|}{ Percentages removed } \\
\hline & & $\mathrm{DBO}_{5}$ & COD & TSS in winter & TSS in spring & Total coliforms & NT & PT \\
\hline \multirow{2}{*}{$50 \%$ coverage } & TRH I & $58 \%$ & $56 \%$ & $-6 \%$ & $18 \%$ & $96 \%$ & $1 \%$ & $13 \%$ \\
\hline & TRH 2 & $31 \%$ & $26 \%$ & $-59 \%$ & $47 \%$ & $91 \%$ & $1 \%$ & $11 \%$ \\
\hline \multirow{2}{*}{$100 \%$ coverage } & TRH I & $2.3 \%$ & $19 \%$ & $-19 \%$ & $62 \%$ & $96 \%$ & $6 \%$ & $-8 \%$ \\
\hline & TRH 2 & $4 \%$ & $0.30 \%$ & $5 \%$ & $39 \%$ & $90 \%$ & $-9 \%$ & $-39 \%$ \\
\hline
\end{tabular}

\section{Acknowledgment}

The National University of Río Cuarto (UNRC), for acceptance of the research and providing the space for the experiment on the campus for the Treatment and Reuse of Urban Effluent Pilot Plant.

\section{Conflicts of interest}

The authors declares that there is no conflict of interest.

\section{References}

1. Jesús González Fernández, Miguel Beascoechea E, Miguel Munoz J, et al. Phytodepuration manual. Chapter 5. Phytodepuration in wetlands. General concepts. Polytechnic University of Madrid. Madrid. Spain. 2005.

2. Robert L Knight, Robert H Kadlec, Mel Wilhelm, et al. Go Ahead. EPA 832-R-93-005. Constructed Wetlands for Wastewater Treatment and Wildlife Habitat. Environmental Protection Agency (EPA). United States. 1993

3. Delgadillo O, Camacho A, Perez Louis F, et al. Wastewater treatment by artificial wetlands. Nelson Antequera Durán. Cochabamba. Bolivia. 2010

4. EPA - Environmental Protection Agency. EPA 832-F-00-023. Technology prospectus Wetlands Subsurface Wastewater free flow. United States. Washington, DC Office of Water. 2000.

5. EPA - Environmental Protection Agency. EPA 832-F-00-024. prospectus technology Humedales wastewater free flow surface. United States. Washington, DC Office of Water. 2000

6. Celia Rodriguez. Constructed wetlands: state of the art (I). Hydraulic and Environmental Engineering, Vol. XXIV, No. 3, 2003. Havana. Cuba. 2003.

7. EPA - Environmental Protection Agency. EPA 625-1-88-022. Design Manual: Constructed Wetlands and Aquatic Plant Systems for Municipal Wastewater Treatment. Environmental Protection Agency (EPA). United States. 1988
8. Gilberto Avila Sotelo. Hydraulic General. Foundations. Volume I. Limusa. Mexico. 1980

9. Saber Abdel, Abdel Aziz, Salam Mohamed El-Shafai. Nutrient recovery from domestic wastewater using a UASB-system duckweed ponds. UNESCO-IHE. Institute for Water Education. Delft. Holland. 2004.

10. Metcalf \& Eddy. Wastewater Engineering. Treatment and Reuse. Mac Graw Hill. $4^{\text {th }}$ Edition. Singapore. 2004.

11. Trujillo García Zarela Miracles. Comparison and evaluation of three water plants to determine the efficiency of nutrient removal in domestic wastewater treatment. National University of Engineering. Faculty of Environmental Engineering. Lime. Peru. 2012.

12. Mary Liz Avendaño Villafranca. Study population of nitrifying bacteria and their relation to the physico-chemical, biological and operational parameters in wastewater treatment system with conventional activated sludge. Polytechnic University of Valencia. Valencia. Spain. 2011.

13. Ana Martinez Ruiz. Implementation of a culture of microalgae for nutrient removal of a previously treated anaerobically urban wastewater Polytechnic university of Valencia. Valencia Spain. 2011.

14. Crespi R, Pugliese M, Soler E, et al. Reuse of sludge generated by domestic wastewater. National University of Río Cuarto. Córdoba. Argentina. 2012.

15. APHA, AWWA, WEF. Standard Methods for the Examination of Water and Wastewater. 19 ${ }^{\text {th }}$ Edition. American Public Health Association. APHA. Washington. US. 1999.

16. Cesar Eduardo Soler. Ideas to investigate. $1^{\text {st }}$ Edition. Ed. Homo Sapiens Rosario de Santa Fe-Argentina. 2009.

17. Ramirez H, Sierra L. Evaluation of the use of duckweed as alternative post-treatment of domestic wastewater effluent oxidation ponds. NOVA - Scientific publication in biomedical publications - ISSN: 1794-2470 Vol.8 No. 13 / January - June 2010 - 1120 Colombia. 2010 